\title{
Movements and diet of the leopard cat Prionailurus bengalensis in a seasonal evergreen forest in south-central Thailand
}

\author{
Lon I. GRASSMAN Jr
}

\begin{abstract}
Grassman L. I. Jr 2000. Movements and diet of the leopard cat Prionailurus bengalensis in a seasonal evergreen forest in south-central Thailand. Acta Theriologica 45: 421-426.

The natural history of the leopard cat Prionailurus bengalensis (Kerr, 1792) was investigated in a seasonal evergreen forest in south-central Thailand by radio telemetry and fecal analysis. Mean overall home range size for male leopard cats $(n=3)$ was 4.1 $\mathrm{km}^{2}\left(\mathrm{SD}=1.23 \mathrm{~km}^{2}\right.$ ) while a female cat exhibited a home range of $2.5 \mathrm{~km}^{2}$. Mean one-day movement was $1.05 \pm 0.35 \mathrm{~km}$. They exhibited arrhythmic activity (mean = $47 \%$ ) dominated by nocturnal and crepuscular tendencies. Peak activity (mean $=58 \%$ ) occurred between $03.01-06.00 \mathrm{~h}$ and $18.01-21.00 \mathrm{~h}$. Analysis of feces $(n=25)$ collected in the field indicated that leopard cats utilized at least 9 prey species dominated by Rattus sp. (28\%). Important secondary prey items included: frogs, Mus sp., siamese hare Lepus peguensis, and tree shrew Tupaia glis.
\end{abstract}

Key words: Prionailurus bengalensis, radio telemetry, movements, diet, tropics

Department of Forest Biology, Kasetsart University, Bangkhen, Bangkok, 10900, Thailand

\section{Introduction}

The leopard cat Prionailurus bengalensis (Kerr, 1792) has one of the largest distributions of wild cats throughout Asia, but there is a conspicuous lack of data on their natural history. There have been only two previous in-depth ecological studies on leopard cats: Rabinowitz (1990) in western Thailand and Izawa et al. (1991) on Tsuchima Island, Japan. It was the intention of this study to add to the paucity of data available on the natural history of leopard cats in Southeast Asia to supplement current management and conservation strategies.

\section{Study area}

Kaeng Krachan National Park (KKNP) is Thailand's largest national park encompassing $2915 \mathrm{~km}^{2}$ (Fig. 1). The general topography consists of forested hills rising westward into mountains. The tropical forest consists of dry and wet evergreen (85\%), mixed deciduous (10\%) and dry dipterocarp (5\%)

Current address: Feline Research Center, Caesar Kleberg Wildlife Research Institute, Texas A\&M Kingsville, Kingsville, Texas 78363, USA 


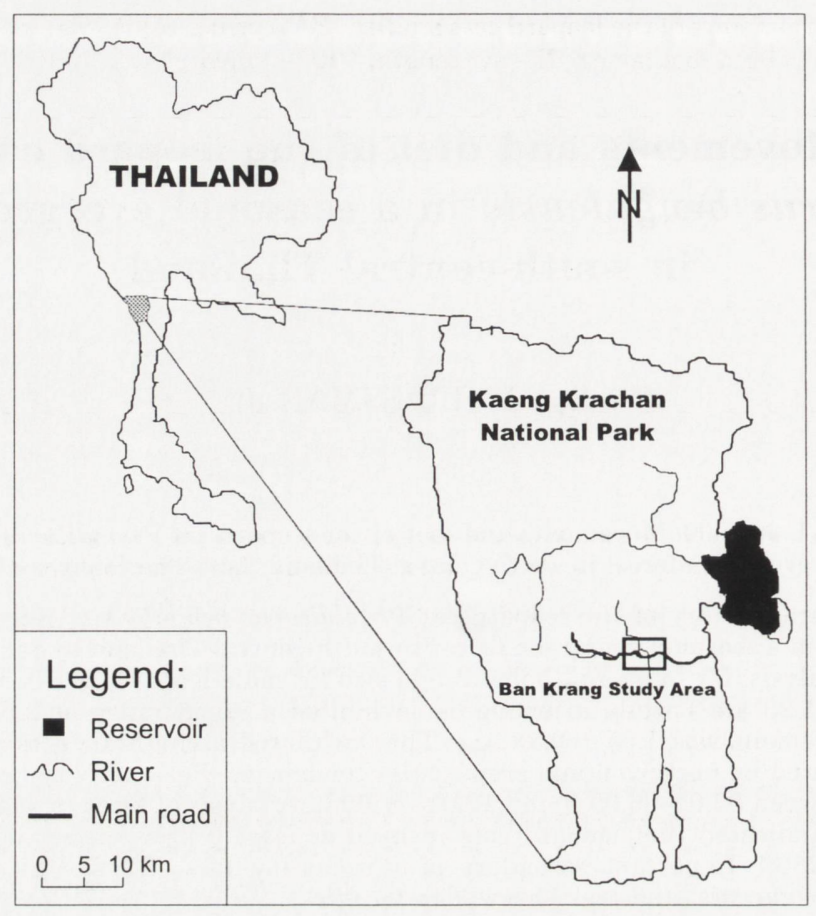

Fig. 1. Kaeng Krachan National Park and Ban Krang Study Area, Thailand.

species (TISTR 1989). The climate of KKNP is essentially under the influence of seasonal monsoons with two distinct seasons: wet (June-October) and the dry season (November-May) (Cummings 1992). Temperatures range from lows of $25^{\circ} \mathrm{C}$ in December to highs of $30^{\circ} \mathrm{C}$ in May with an annual mean of $28^{\circ} \mathrm{C}$. The study area was restricted to a $60-\mathrm{km}^{2}$ area in the south-central portion of the park at the Ban Krang Camping Area. The area consisted of hilly/mountainous terrain at 500-800 m elevation. A main road traversed the study area running east and west. Smaller trails and the Pranburi River were also included within the study area.

\section{Material and methods}

Leopard cats were captured with home-made medium sized steel $(150 \times 40 \times 50 \mathrm{~cm})$ and small Tomahawk ${ }^{\circledR}$ (Tomahawk Co., USA; $107 \times 40 \times 40 \mathrm{~cm}$ ) box traps baited with chickens. Traps were set along the main road, trails and riverbanks where leopard cat sign occurred in the form of spoor or scat and checked daily. Captured cats were anesthetized via intramuscular injection of ketamine hydrochloride, (Calypso®, Gedeon Richter, Co., Hungary) at $25 \mathrm{mg} / \mathrm{kg}$. Cats were sexed, aged, weighed and standard body measurements recorded. Four age classifications were assigned using tooth wear, body size and overall body condition: juvenile (J), young adult (YA), prime adult (PA), and old adult (OA). Adult cats were fitted with a butyl, collar-mounted radio transmitter with activity sensor (Wildlife Materials®, Inc., USA) at $142 \mathrm{MHz}$. Signal range varied from 1 to $15 \mathrm{~km}$ depending upon the obstruction of terrain and the elevation at which the signal was received. All tracking was conducted on the ground from hilltop stations using a H-element antenna. Leopard cats were radio tracked intermittently during both diurnal and nocturnal time periods. The convex polygon method (Mohr 
Table 1. Physical parameters of the leopard cats studied (PA - prime adult, HB - head and body length, $\mathrm{TL}$ - tail length, HF - hind foot length, E - ear length, URC - upper right canine length). M - male, F female.

\begin{tabular}{lccccccc}
\hline & & \multicolumn{5}{c}{ Body measurements } \\
Animals & Age & Weight $(\mathrm{kg})$ & HB $(\mathrm{cm})$ & TL $(\mathrm{cm})$ & HF $(\mathrm{cm})$ & $\mathrm{E} \mathrm{(cm)}$ & URC (mm) \\
\hline M1 & PA & 3.0 & 58 & 26 & 11 & 4 & 11 \\
F1 & PA & 2.7 & 56 & 26 & 11 & 4.3 & 10 \\
M2 & PA & 3.5 & 57 & 27 & 12 & 5 & 11 \\
M3 & PA & 3.5 & 60 & 26 & 12 & 4.5 & 12 \\
\hline
\end{tabular}

1947) was used for annual and seasonal home range and home range overlap estimates. All plotted points were used to estimate home range size. Daily movements were calculated by measuring the linear distance between consecutive 24-hour locations (Rabinowitz 1990).

Analysis of diet was based on examination of 25 scats collected in the field. Due to the potential for confusing leopard cat scat with other small carnivore scat in the area only those samples accompanied by leopard cat spoor were accepted. Hair cuticular and medullar characteristics were compared with known specimens in a reference collection (Putman 1984). The diet was compared to the wet and dry seasons and focused on frequency of occurrence.

Between 14 June 1996 and 26 February 1997 three adult male and one adult female leopard cats were captured, radio collared, and monitored for two to nine months. All cats were aged as prime adults and released in good physical condition (Table 1). A total of 292 radio locations were recorded for these four cats to calculate home range size.

\section{Results and discussion}

\section{Home range size and movements}

The overall home range size of males M1, M2 and M3 were $5.8,3.3$ and $3.1 \mathrm{~km}^{2}$ respectively, while female $\mathrm{F} 1$ exhibited a home range of $2.5 \mathrm{~km}^{2}$ (Table 2). Males M1 and M2 showed overlapping ranges of $2.4 \%$, while female F1's home range overlapped with male M2 by $46.2 \%$ and with M1 by $5.3 \%$ (Fig. 2). Male M3 occupied a home range independent from other study leopard cats.

Table 2. Overall home range size, seasonal size and mean daily movements of the four leopard cats in KKNP, Thailand.

\begin{tabular}{lcccccc}
\hline Animals & $\begin{array}{c}\text { Duration } \\
\text { tracked } \\
(\text { days })\end{array}$ & $\begin{array}{c}\text { Radio } \\
\text { locations } \\
(n)\end{array}$ & Overall & Wet season & Dry season & $\begin{array}{c}\text { Mean daily } \\
\text { movements } \\
(\mathrm{km})\end{array}$ \\
\hline M1 & 258 & 112 & 5.8 & 5.4 & 5.2 & 1.0 \\
F1 & 229 & 129 & 2.5 & 2.5 & 2.5 & 0.6 \\
M2 & 47 & 32 & 3.3 & - & 3.3 & 1.0 \\
M3 & 47 & 19 & 3.1 & - & 2.3 & 1.6 \\
\hline
\end{tabular}




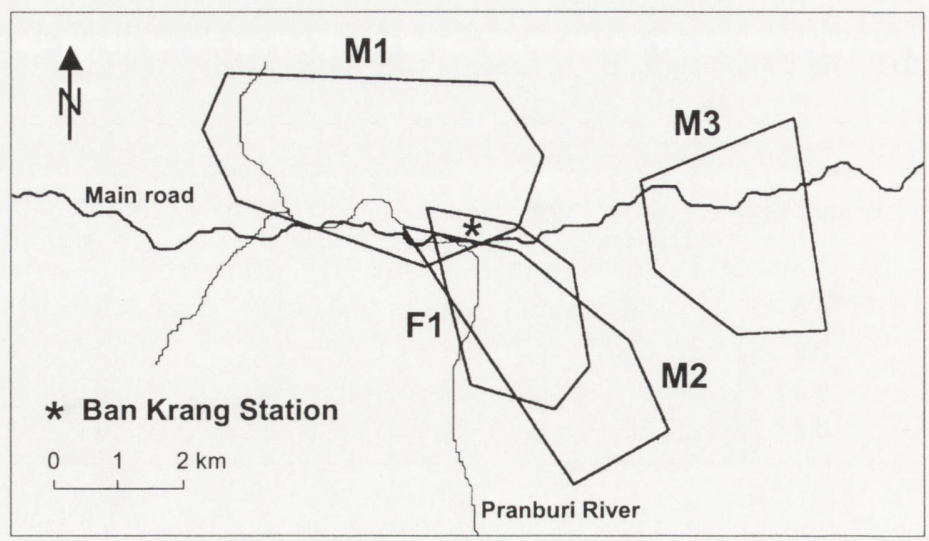

Fig. 2. Overall home ranges of the four leopard cats in Ban Krang Study Area, KKNP, Thailand.

Leopard cat males in KKNP showed significant variation in overall home range size. This variation may have been due to the short period of time two of the three males were tracked. M2 and M3, both captured on 10 January 1997 were radio tracked for only 7 weeks. Their relatively small home ranges would likely have increased through additional radio tracking. However, home range size data on M1 and F1 are likely comprehensive as these cats were tracked for 7 and 8 months and both reached $95 \%$ of their overall home range size after three months.

The home range size of male M1 was more than twice as large as female F1. Previous studies on other small felids reflect a similar pattern. Bobcat Lynx rufus and ocelot Leopardus pardalis males were shown to have substantially larger home ranges than females (Litvaitis et al. 1986, Ludlow and Sunquist 1987, Konecny 1990).

Leopard cats were located on consecutive days 134 times for which a mean one-day movement of $1.05 \mathrm{~km}(\mathrm{SD}=0.35 \mathrm{~km}$ ) was recorded (Table 2). Mean one-day movement was similar to that for leopard cats in Huai Kha Khaeng $(0.78$ $\mathrm{km}, n=100$ ) (Rabinowitz 1990). Adequate prey densities likely resulted in that leopard cats were not obliged to travel greater distances in-between hunting sorties as previously seen in felids which inhabit low prey density habitat (Knowles 1985, Sunquist and Sunquist 1989).

Cats were classified as active during $47 \%$ of activity readings. They exhibited arrhythmic activity dominated by nocturnal and crepuscular tendencies with activity peaks between $21.01-24.00 \mathrm{~h}$ and $03.01-06.00 \mathrm{~h}$ (mean $=58 \%$ of activity readings; Fig. 3). Peak inactivity occurred at around mid-day (30\% active). Highest average monthly activity (51\%) was recorded during the wet season in July, while the lowest $(45 \%)$ was recorded during the dry season in March.

The lack of seasonal change in home range size and activity was likely due to the relatively stable environment of KKNP; specifically prey availability and the absence of extreme seasonal weather. Rabinowitz (1990) attributed variation in 
Fig. 3. Mean activity pattern of the four leopard cats in KKNP, Thailand ( $n=1,620$ activity readings).

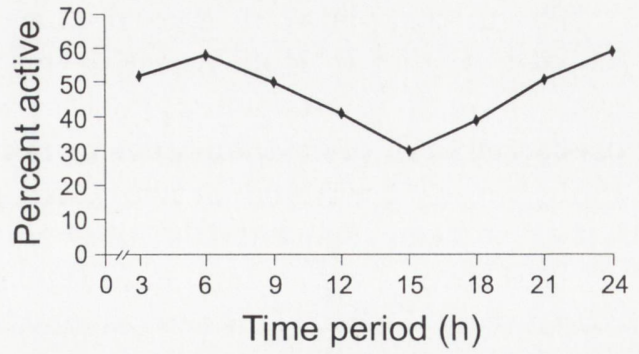

leopard cat activity levels and home range size to seasonal forest fires and flooding in Huai Kha Khaeng.

\section{Food habits}

Scat analysis revealed that leopard cats utilized at least nine prey species (Table 3). Each identified fecal sample contained only one prey item. Rattus sp. was the most common prey item found (28\%), while Mus sp., siamese hare Lepus peguensis and tree shrew Tupaia glis were important secondary items at $8 \%$ frequency of occurrence respectively. Four unidentified small mammal remains originated from Rodentia or Insectivora. Five unidentified animal remains originated from frogs or other amphibians due to lack of hair and presence of partialy ossified bones recovered from feces. These remains were found only during the wet season when frogs were abundant on the road.

Table 3. Frequency of occurrence of prey items identified from leopard cat feces $(n=25)$ from Ban Krang Study Area, KKNP, Thailand.

\begin{tabular}{lcc}
\hline & \multicolumn{2}{c}{ Frequency of occurrence } \\
\cline { 2 - 3 } Prey species & $(n)$ & $(\%)$ \\
\hline Muridae & 7 & 28 \\
$\quad$ Rattus sp. & 2 & 8 \\
Mus sp. & & \\
Sciuridae & 1 & 4 \\
$\quad$ Menetes berdmorei & & \\
Leporidae & 2 & \\
Lepus peguensis & & \\
Tupaidae & 2 & \\
$\quad$ Tupaia glis & & 4 \\
Cercopithecidae & 1 & 16 \\
$\quad$ Semnopithecus obscura & 4 & 20 \\
Unidentified small mammal & 5 & 4 \\
Unidentified amphibian & 1 & \\
Bird & 25 & \\
Total &
\end{tabular}


The dietary data on leopard cats coincide with Rabinowitz's (1990) data on leopard cat diet in Huai Kha Khaeng where murid representation accounted for over one-half of frequency of occurrence. KKNP leopard cats utilized murids proportionately more than other mammalian families (36\%). Leopard cats from the Philippines (Alcala and Brown 1969) and Tsushima Island, Japan (Inoue 1972) have also been reported to utilize rats and mice extensively.

Tree shrews were common in the study area and were often seen crossing the road during the day. This species may have played an important role in leopard cat diet during diurnal hours, although their representation within scats collected was modest. The utilization of frogs or other amphibians constituted a large proportion of leopard cat feces and were likely important prey items during the wet season.

Acknowledgements: I thank K. Sukgao, U. Grassman and S. Austin for their assistance with field data collection. Permission for this study was granted by the Royal Forest Department, National Parks Department and National Research Council of Thailand. This study was funded by Societa Zoologica La Torbiera.

\section{References}

Alcala A. C. and Brown W. C. 1969. Notes on the food habits of three Philippine wild mammals. Silliman Journal 16: 91-94.

Cummings J. 1992. Thailand: A travel survival kit. Lonely Planet Publications, Hawthorn, Australia: 1-626.

Inoue T. 1972. The food habit of the Tsushima leopard cat (Felis bengalensis spp.) analysed for their scats. Journal of the Mammalogical Society of Japan 5: 155-169.

Izawa M. T., Doi T. and Ono Y. 1991. Ecological study on two species of Felidae in Japan. [In: Wildlife Conservation: present trends and perspectives for the 21st century. Procedings of the 5th International Congress of Ecology. N. Maruyama et al., eds]. Yokohama, Japan: 141-143.

Knowles P. R. 1985. Home range size and habitat selection of bobcats (Lynx rufus) in north-central Montana. Canadian Field Naturalist 99: 6-12.

Konecny M. J. 1990. Movement patterns and food habits of four sympatric carnivore species in Belize, Central America. [In: Advances in neotropical mammalogy. K. K. Redford and J. F. Eisenberg, eds]. University of California Press, Berkley: 243-264.

Litvaitis J. A., Sherburne J. A. and Bissonette J. A. 1986. Bobcat habitat use and home range size in relation to prey density. The Journal of Wildlife Management 50: 110-117.

Ludlow M. E. and Sunquist M. E. 1987. Ecology and behavior of ocelots in Venezuela. National Geographic Research 30: 447-461.

Mohr C. O. 1947. Table of equivelant populations of North American small mammals. American Midland Naturalist 37: 223-249.

Putman R. J. 1984. Facts from faeces. Mammal Review 140: 17-25.

Rabinowitz A. 1990. Notes on the behavior and movements of leopard cats (Felis bengalensis) in a dry tropical forest mosaic in Thailand. Biotropica 22: 397-403.

Sunquist M. and Sunquist F. 1989. Ecological constraints on predation by large felids. [In: Carnivore Behavior, Ecology and Evolution. J. Gittleman, ed]. Cornell University Press, New York: 283-301.

TISTR. 1989. [Master plan for Kaeng Krachan National Park]. Thailand Institute of Scientific and Technological Research, Bangkok: 1-105. [In Thai]

Received 20 January 1999, accepted 12 November 1999. 